Article

\title{
Antioxidant and Antimicrobial Evaluation and Chemical Investigation of Rosa gallica var. aegyptiaca Leaf Extracts
}

\author{
Ahmed S. Abdelbaky ${ }^{1, *(D)}$, Abir M. H. A. Mohamed ${ }^{2}$ and Salman S. Alharthi $^{3}$ (D) \\ 1 Department of Biochemistry, Faculty of Agriculture, Fayoum University, Fayoum 63514, Egypt \\ 2 Department of Agricultural Microbiology, Faculty of Agriculture, Fayoum University, Fayoum 63514, Egypt; \\ amh05@fayoum.edu.eg \\ 3 Department of Chemistry, College of Sciences, Taif University, P.O. Box 11099, Taif 21944, Saudi Arabia; \\ s.a.alharthi@tu.edu.sa \\ * Correspondence: asm03@fayoum.edu.eg; Tel.: +20-10-190-96-097
}

Citation: Abdelbaky, A.S.; Mohamed, A.M.H.A.; Alharthi, S.S. Antioxidant and Antimicrobial Evaluation and Chemical Investigation of Rosa gallica var. aegyptiaca Leaf Extracts. Molecules 2021, 26, 6498. https://doi.org/ $10.3390 /$ molecules 26216498

Academic Editor: Francesco Cacciola

Received: 27 September 2021

Accepted: 26 October 2021

Published: 27 October 2021

Publisher's Note: MDPI stays neutral with regard to jurisdictional claims in published maps and institutional affiliations.

Copyright: (c) 2021 by the authors. Licensee MDPI, Basel, Switzerland. This article is an open access article distributed under the terms and conditions of the Creative Commons Attribution (CC BY) license (https:// creativecommons.org/licenses/by/ $4.0 /)$.

\begin{abstract}
Rosa gallica var. aegyptiaca is a species of flowering plant belonging to the Rosaceae family that plays an important role as a therapeutic agent for the treatment of specific types of cancer, microbial infections, and diabetes mellitus. This work presents the first report on the evaluation of the antioxidant and antimicrobial potential along with the phytochemical analysis of Rosa gallica var. aegyptiaca leaves. Five leaf extracts of hexane, chloroform, methanol, hydromethanol $80 \%$, and water were prepared. Assessment of antioxidant activity was carried out via DPPH radical scavenging assay. Antimicrobial activity against five foodborne pathogenic bacteria-including Listeria monocytogenes, Bacillus subtilis, Staphylococcus aureus, Escherichia coli, and Salmonella enteritidisand the fungus Candida albicans, was examined using the disc diffusion method. Total phenolic content and total flavonoid content were determined using the Folin-Ciocalteu reagent and aluminum chloride methods, respectively. Isolation, identification, and quantification of phenolic compounds were performed using HPLC-DAD analysis. Amongst the five leaf extracts that were investigated, hydromethanol $80 \%$ extract possessed the highest extraction yield, antioxidant activity, total phenolic content, and antimicrobial activity against all tested microbial strains. Moreover, this extract furnished six active phenolic compounds: gallic acid (1), (+) catechin (2), chlorogenic acid (3), (-) epicatechin (4), quercetin-3-O- $\alpha$-D-(glucopyranoside) (5), and quercetin (6). This study provides an alternative utilization of $R$. gallica var. aegyptiaca leaves as a readily accessible source of natural antioxidants and antimicrobials in the food and pharmaceutical industries.
\end{abstract}

Keywords: $R$. gallica var. aegyptiaca; antioxidant activity; antimicrobial activity; plant extracts; HPLC-DAD; total phenolic content

\section{Introduction}

Plants are powerful sources of potentially effective natural antioxidants and antimicrobial agents, and have attracted great interest recently. Several studies have been conducted in an attempt to discover natural antioxidant compounds that could potentially replace synthetic antioxidants [1]. Currently, synthetic antioxidants such as butylated hydroxytoluene (BHT, E321), tert-butylhydroquinone (TBHQ, E319), and butylated hydroxyanisole (BHA, E320) are commonly used in food for the prevention of oxidative deterioration [2]. It has been reported that these synthetic antioxidants are involved in some harmful side effects, such as the promotion of tumors, causing toxicity and cancer, as well as the wide rejection by consumers of synthetic food additives [3-5]. As a result, there is a need to search for novel and safe antioxidants derived from natural sources, which are more efficient and less hazardous.

On the other hand, food poisoning is quite possibly the most widely recognized reason for illness and death caused by microorganisms in developing and third-world nations [6-8]. The consumption of foods contaminated with some microorganisms-particularly Gram (-) 
bacteria such as Escherichia coli, Salmonella typhi, and Pseudomonas aeruginosa [9,10], as well as Gram (+) bacteria such as Staphylococcus aureus and Bacillus cereus [11]—represents a significant health risk to humans. The survival and growth of microorganisms (especially bacteria) in foods causes spoilage, toxin formation, and quality deterioration in food products [12]. Due to the resistance that pathogenic bacteria and fungi possess against antibiotics, there is a lot of interest in finding new, healthier, safer, and potentially effective antimicrobial drugs from natural sources. In these contexts, natural plant extracts are used as antimicrobial agents for food poisoning diseases. These plant extracts and bioactive substances obtained from plant species can be utilized in folk medicine, and as a productive resource for such new medications [13]. Recently, many studies on antimicrobial activities using different plant extracts have revealed that the phenolic and flavonoid compounds found in plant extracts may also play a significant role in their antimicrobial action [13,14].

$R$. gallica var. aegyptiaca (Rosaceae) is considered one of the most widely important popular garden shrubs for the flavor, cosmetics, and fragrance industries [15]. Some Rosa species-such as $R$. damascena, $R$. sempervirens, and $R$. villosa-are commonly used for different therapeutic purposes, such as treatment of hemorrhoids, dyspepsia, or nephritis; as an expectorant, diuretic, stomachic, or tonic agent; for inflammations [16,17]; as an analgesic; to treat injuries; as a gastroprotective; or for certain types of cancer, microbial infections, diarrhea, or diabetes mellitus [18-21] —due to the presence of various phenolics, e.g., phenolic acids and flavonoids, terpenes, and essential oils in Rosa spp., which directly or indirectly contribute to their biochemical activities [22-28]. Moreover, some researchers found that various extracts and essential oils derived from several Rosa spp. possess strong antioxidant and antimicrobial activities [25-30].

Despite the popular use of Rosa species as therapeutic agents, to date there have been no data regarding their antioxidant and antimicrobial effects against foodborne pathogenic bacteria-including Listeria monocytogenes, Bacillus subtilis, Staphylococcus aureus, Escherichia coli, and Salmonella enteritidis, as well as the fungus Candida albicans—or the chemistry of Rosa gallica var. aegyptiaca leaf extracts. Thus, the present study aims to evaluate their antioxidant and antimicrobial activities, in addition to phytochemical analysis.

\section{Results and Discussion}

\subsection{Qualitative Phytochemical Screening}

Phytochemical screening of the dry powdered leaves of R. gallica var. aegyptiaca was carried out for the detection of various phytochemical constituents, and the results are presented in Table 1, which reveals the presence of saponins, triterpenoids, phenolics, tannins, flavonoids, alkaloids, glycosides, and carbohydrates, but no steroids.

Table 1. Qualitative phytochemical screening of $R$. gallica var. aegyptiaca leaves.

\begin{tabular}{ccc}
\hline Constituent & Detection Test & Result \\
\hline Saponins & Foam test & + \\
Steroids & Liebermann-Burchard test & - \\
Triterpenoids & Salkowski reaction & + \\
Phenolic compounds and tannins & Ferric chloride test & + \\
Flavonoids & Lead acetate test & + \\
Alkaloids & Wagner's tests & + \\
Glycosides & Keller-Kiliani test & + \\
Carbohydrates & Molisch's test & + \\
\hline
\end{tabular}

(+): present; (-): absent.

\subsection{Extraction Yields}

The components of $R$. gallica var. aegyptiaca were extracted using solvents with increasing polarity: n-hexane $\left(\mathrm{C}_{6} \mathrm{H}_{14}\right)$, chloroform $\left(\mathrm{CHCl}_{3}\right)$, methanol $(\mathrm{MeOH})$, hydromethanol $80 \%\left(\mathrm{MeOH} / \mathrm{H}_{2} \mathrm{O} 80 \%\right)$, and water $\left(\mathrm{H}_{2} \mathrm{O}\right)$. The product of extractable compounds (residues) 
relative to the weight of air-dried powdered leaves ranged from $1.6 \%$ (n-hexane extract) to 9.9\% (hydromethanol extract) Table 2.

Table 2. Extraction yield, antioxidant activity (DPPH inhibition percentage), $\mathrm{IC}_{50}$, total phenolics (TPs), and total flavonoids (TFs) of R. gallica var. aegyptiaca leaf extracts.

\begin{tabular}{|c|c|c|c|c|c|}
\hline Extract & $\begin{array}{l}\text { Extract Yield } \\
(\%)\end{array}$ & $\begin{array}{l}\text { Inhibition Percentage } \\
\qquad(50 \mu \mathrm{g} / \mathrm{mL})\end{array}$ & $\begin{array}{c}\mathrm{IC}_{50} \\
(\mu \mathrm{g} / \mathrm{mL})\end{array}$ & $\begin{array}{c}\text { TPs } \\
\text { (mg GAE } \mathrm{g} / \mathrm{g} \text { Extract) }\end{array}$ & $\begin{array}{c}\text { TFs } \\
\text { (mg RE }{ }^{\mathrm{r} / g} \text { Extract) }\end{array}$ \\
\hline $\mathrm{C}_{6} \mathrm{H}_{14}$ & 1.6 & $20 \pm 1.0^{c}$ & & $20.00 \pm 2.46^{\mathrm{e}}$ & $5.300 \pm 1.25^{\mathrm{d}}$ \\
\hline $\mathrm{CHCl}_{3}$ & 6.5 & $15 \pm 85^{\mathrm{d}}$ & & $25.00 \pm 3.10^{d}$ & $6.500 \pm 1.50^{c}$ \\
\hline $\mathrm{MeOH}$ & 9.2 & $95.08 \pm 0.33^{b}$ & $20.28 \pm 0.97^{b}$ & $181.6 \pm 0.83^{b}$ & $54.48 \pm 1.79^{a}$ \\
\hline $\mathrm{MeOH} / \mathrm{H}_{2} \mathrm{O} 80 \%$ & 9.9 & $97.20 \pm 0.25^{\mathrm{a}}$ & $19.38 \pm 0.85^{a}$ & $253.8 \pm 1.26^{a}$ & $41.02 \pm 1.55^{b}$ \\
\hline $\mathrm{H}_{2} \mathrm{O}$ & 4.1 & $10 \pm 1.1^{\mathrm{e}}$ & & $50.83 \pm 1.25^{c}$ & $1.700 \pm 0.22^{\mathrm{e}}$ \\
\hline L-Ascorbic Acid & & & $21.30 \pm 0.55^{c}$ & & \\
\hline
\end{tabular}

Values are expressed as mean $\pm \mathrm{SD}, n=3$. Means within each column with different letters ${ }^{\mathrm{a}-\mathrm{e}}$ ) are significantly different $(p<0.05)$; ${ }^{\mathrm{g}} \mathrm{GAE}$ : gallic acid equivalents; ${ }^{\mathrm{r}} \mathrm{RE}$ : rutin equivalents. Means sharing the same letter for each parameter are not significantly different according to LSD as a post hoc test at $p \leq 0.05$.

\subsection{Antioxidant Activity via DPPH Free Radical Scavenging Assay}

A DPPH assay at $50 \mu \mathrm{g} / \mathrm{mL}$ was used to determine the antioxidant activity of $R$. gallica var. aegyptiaca leaf extracts. The results (Table 2 ) are presented as inhibition percentage of free radical DPPH. As shown in Table 2, the highest free radical scavenging activity (FRSA) values were noted for $\mathrm{MeOH} / \mathrm{H}_{2} \mathrm{O} 80 \%(97.2 \%)$, followed by $\mathrm{MeOH}(95.08 \%)$, while the lowest values were detected in extracts of $\mathrm{C}_{6} \mathrm{H}_{14}(20 \%), \mathrm{CHCl}_{3}(15 \%)$, and $\mathrm{H}_{2} \mathrm{O}(10 \%)$. The variation in DPPH FRSA could be related to the variances in their secondary constituents-particularly phenolics [31,32]. The high antioxidant activity of the $\mathrm{MeOH} / \mathrm{H}_{2} \mathrm{O} 80 \%$ and $\mathrm{MeOH}$ extracts was then used to estimate their $\mathrm{IC}_{50}$ values-the concentration of a substance required to inhibit $50 \%$ of the DPPH free radicals. The $\mathrm{IC}_{50}$ values of $\mathrm{MeOH} / \mathrm{H}_{2} \mathrm{O} 80 \%$ and $\mathrm{MeOH}$ leaf extracts of $R$. gallica var. aegyptiaca, along with L-ascorbic acid (positive control), are presented in Table 2. As shown in the table, the highest DPPH FRSA was obtained in the $\mathrm{MeOH} / \mathrm{H}_{2} \mathrm{O} 80 \%$ extract, with the lowest $\mathrm{IC}_{50}$ of $19.38 \pm 0.38 \mu \mathrm{g} / \mathrm{mL}$, followed by the $\mathrm{MeOH}$ extract, with $20.28 \pm 0.97 \mu \mathrm{g} / \mathrm{mL}$. These $\mathrm{IC}_{50}$ values of the $\mathrm{MeOH} / \mathrm{H}_{2} \mathrm{O} 80 \%$ and $\mathrm{MeOH}$ were found to be stronger antioxidants than the methanol extract of white Rose, whose $\mathrm{IC}_{50}$ value was $43.8 \mu \mathrm{g} / \mathrm{mL}$ [33]. Moreover, the antioxidant activity of $\mathrm{MeOH} / \mathrm{H}_{2} \mathrm{O} 80 \%$ and $\mathrm{MeOH}$ of $R$. gallica var. aegyptiaca on DPPH FRSA was found to be superior to that of Rosa agrestis ethyl acetate leaf extract $\left(\mathrm{IC}_{50}=47.43 \mu \mathrm{g} / \mathrm{mL}\right)$ [26], and the $\mathrm{MeOH} / \mathrm{H}_{2} \mathrm{O} 80 \%$ also showed a superior-excellent antioxidant activity compared with the conventional reference L-ascorbic acid (AA), with an $\mathrm{IC}_{50}$ of $21.30 \mu \mathrm{g} / \mathrm{mL}$ (Figure 1 and Table 2). Therefore, the $\mathrm{MeOH} / \mathrm{H}_{2} \mathrm{O} 80 \%$ and $\mathrm{MeOH}$ extracts showed potent DPPH FRSA, indicating that $R$. gallica var. aegyptiaca leaves contain notable antioxidant compounds. These results indicate that both $\mathrm{MeOH} / \mathrm{H}_{2} \mathrm{O} 80 \%$ extract and $\mathrm{MeOH}$ extract possess powerful antioxidant compounds, which may be responsible for their antioxidant activities, suggesting that this plant represents a promising source of natural antioxidants.

\subsection{Total Phenolic and Flavonoid Contents}

It is generally recognized that phenolic and flavonoid compounds play a direct role in plant biological activities, such as antioxidant [34] and antimicrobial [14] activity. Therefore, the TPC and TFC in the five different leaf extracts were determined. As presented in Table 2, the TPC and TFC of all leaf extracts differed significantly. The $\mathrm{MeOH} / \mathrm{H}_{2} \mathrm{O}$ $80 \%$ (253.8 $\pm 1.26 \mathrm{mg}$ GAE/g dried leaf extract) had the highest TPC level, followed by the $\mathrm{MeOH}(181.6 \pm 0.83)$, while the TPC of the $\mathrm{H}_{2} \mathrm{O}, \mathrm{CHCl}_{3}$, and $\mathrm{C}_{6} \mathrm{H}_{14}$ were the lowest $(50.83 \pm 1.25,25.00 \pm 3.10$, and $20.00 \pm 2.46 \mathrm{mg} \mathrm{GAE} / \mathrm{g}$ of dried leaf extract, respectively). The TPC of the $\mathrm{MeOH} / \mathrm{H}_{2} \mathrm{O} 80 \%$ was observed to be higher than the values stated by Bitis et al. [16] for R. sempervirens L. leaves (203.8 mg GAE/g), by Ozkan et al., [35] for R. damascena dried flower extracts (248.97 mg GAE/g), and by Nowak and Gawlik-Dziki [28] 
for R. canina var. dumalis leaves (15.2 mg GAE/g). These results are in accordance with those reported by Peschel et al. [36], who found that aqueous methanol (75\%) is the most appropriate solvent for the extraction of phenolic compounds.

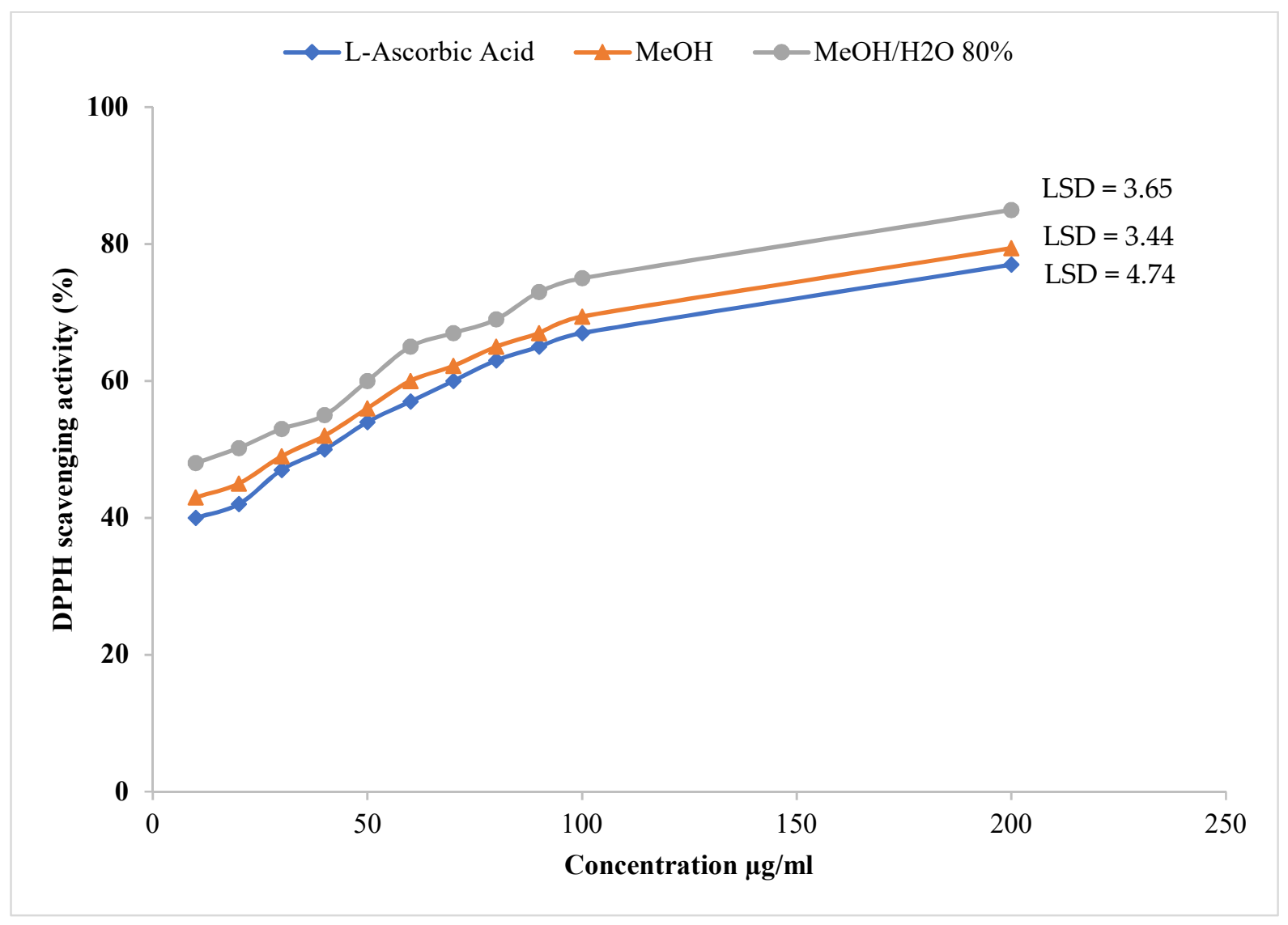

Figure 1. DPPH FRSA of $\mathrm{MeOH} / \mathrm{H}_{2} \mathrm{O} 80 \%$ and $\mathrm{MeOH}$ leaf extracts of $R$. gallica var. aegyptiaca, compared with L-ascorbic acid (AA) $(n=3)$. LSD as a post hoc test at $p \leq 0.05$ was used to separate the means of the treatments.

The TFC of $R$. gallica var. aegyptiaca leaf extracts ranged from $1.700 \pm 0.22$ to $54.48 \pm 1.79 \mathrm{mg}$ RE/g of dried leaf extract. As shown in Table 2, the highest TFC of $54.48 \pm 1.79$ was observed in $\mathrm{MeOH}$, followed by $\mathrm{MeOH} / \mathrm{H}_{2} \mathrm{O} 80 \%$ extract (41.02 $\pm 5.55 \mathrm{mg} \mathrm{RE} / \mathrm{g}$ ), whereas the $\mathrm{CHCl}_{3}, \mathrm{C}_{6} \mathrm{H}_{14}$, and $\mathrm{H}_{2} \mathrm{O}$ leaf extracts showed the lowest TFCs of $6.500 \pm 1.50,5.300 \pm 1.25$, and $1.700 \pm 0.22 \mathrm{mg} \mathrm{RE} / \mathrm{g}$ of dried extract, respectively. A similar finding that TFC in methanol extract is higher than in hydromethanol extract was observed by Tatke et al. [37]. The differences in the phytoconstituents may be explained by the use of extracting solvents that possess different natures and a variety of phenolic compounds. This perception leads to the inference that the potent antioxidant activity is due to the high amounts of soluble phenolic compounds in the most effective extracts.

\subsection{HPLC-DAD Analysis}

HPLC-DAD analysis of $\mathrm{MeOH} / \mathrm{H}_{2} \mathrm{O} 80 \%$ leaf extract furnished six phenolic compounds: gallic acid (1), (+) catechin (2), chlorogenic acid (3), (-) epicatechin (4), quercetin-3$O-\alpha$-D-(glucopyranoside) (5), and quercetin (6), which were identified by comparing their retention times and UV spectra to those of the standards, as shown in Figure 2 and Table 3, respectively. Also, the data of the HPLC-ESI-MS (Supplementary Materials, Figure S1) of the active fraction has confirmed the presence of these compounds. 


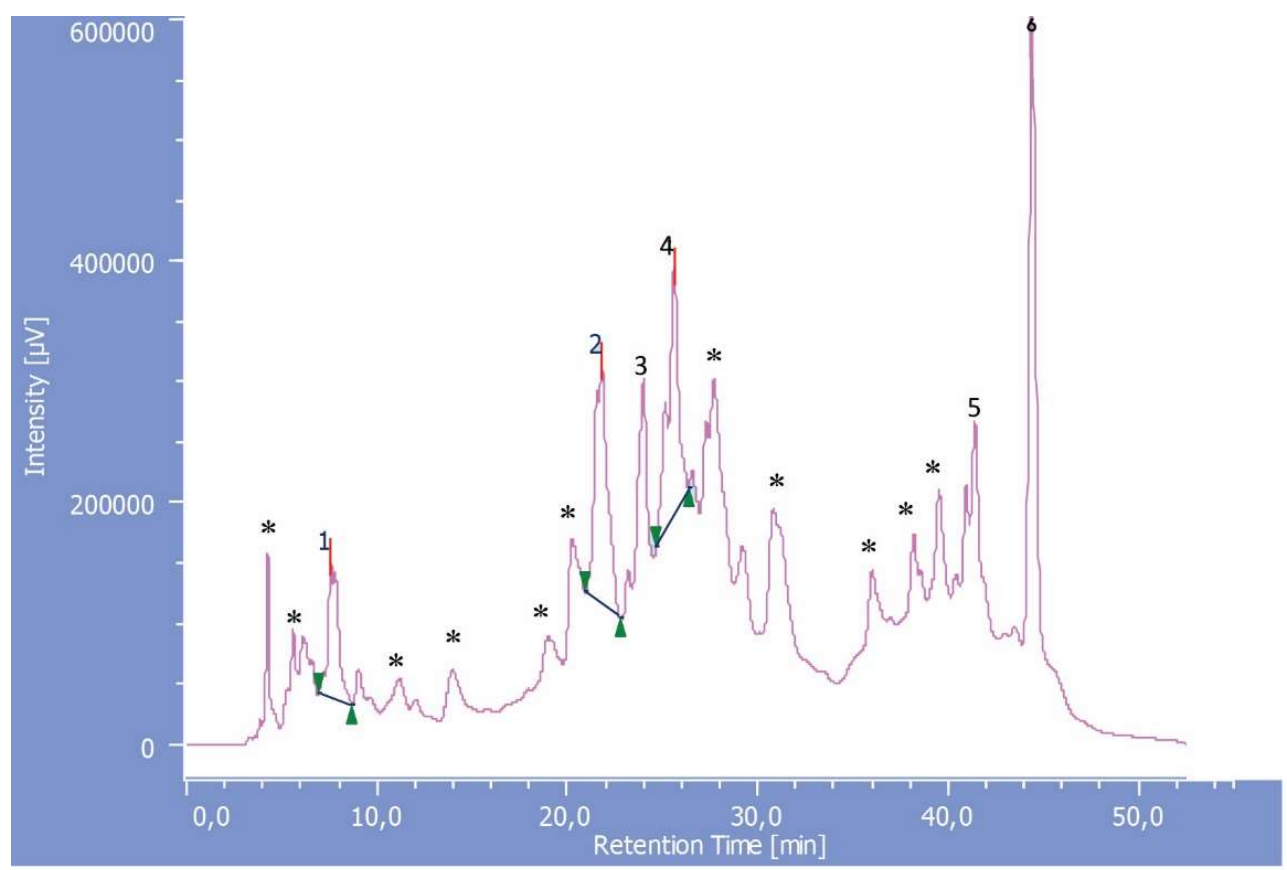

Figure 2. HPLC-DAD chromatogram of $\mathrm{MeOH} / \mathrm{H}_{2} \mathrm{O} 80 \%$ extract of $R$. gallica var. aegyptiaca leaves. The figure shows the chromatographic separation of phenolic compounds based on the following conditions: Column, Zorbax $\mathrm{C}_{18}, 5 \mu \mathrm{m}, 280 \times 4.6 \mathrm{~mm}$ i.d.; detection at 350, 325, and $280 \mathrm{~nm}$; flow rate, $0.5 \mathrm{~mL} / \mathrm{min}$; gradient elution system of methanol/water/formic acid; injected volume, $10 \mu \mathrm{L}$. Peaks: (1) gallic acid; (2) (+) catechin; (3) chlorogenic acid; (4) (-) epicatechin; (5) quercetin-3-O- $\alpha$-D -(glucopyranoside); (6) quercetin; $\left(^{*}\right)$ unknown peaks.

Table 3. Identification and quantification of the phenolic compounds present in $\mathrm{MeOH} / \mathrm{H}_{2} \mathrm{O} 80 \%$ leaf extract of $R$. gallica var. aegyptiaca via HPLC-DAD.

\begin{tabular}{cccc}
\hline Peak & Rt $(\mathbf{m i n})$ & Compound & $\mathbf{m g} / \mathbf{g}$ \\
\hline 1 & 7.56 & Gallic acid & 1.7 \\
2 & 21.77 & Catechin & 2.9 \\
3 & 23.68 & Chlorogenic acid & 1.8 \\
4 & 25.56 & Epicatechin & 2.6 \\
5 & 41.30 & quercetin-3-O- $\alpha-\mathrm{D}-$ & 0.5 \\
6 & 44.33 & (glucopyranoside) & 19.8 \\
\hline
\end{tabular}

Phenolics and flavonoids possess different antioxidant efficiency, depending on their structural conformation, number, and arrangement of the $(-\mathrm{OH})$ groups and their localization in the structure [38-40]. Generally, both phenolic acids and other flavonoids such as flavonols and flavanols are considered to be effective hydrogen donors because of their carboxylic acid group and hydroxyl functional groups, which are easily ionized [41]. In this study, phenolic acids such as gallic and chlorogenic acids (peaks 1 and 3) were identified at amounts of 1.7 and $1.8 \mathrm{mg} / \mathrm{g}$, respectively. In addition to other flavonoids, $(+)$ catechin, $(-)$ epicatechin, and quercetin-3-O- $\alpha$-D-(glucopyranoside) (peaks 2, 4, and 5, respectively) were identified in acceptable amounts, while quercetin (peak 6) was present in a high amount $(19.8 \mathrm{mg} / \mathrm{g})$, and was considered to be the main component.

The $\mathrm{MeOH} / \mathrm{H}_{2} \mathrm{O} 80 \%$ extract from $R$. gallica var. aegyptiaca leaves contained the highest concentration of flavonol (quercetin), which may be very interesting, since this compound has been correlated with various biological effects, including antioxidant, anti-inflammatory, anticarcinogenic, antiviral, antibacterial, antifungal, antitumor, antiallergenic, and antithrombotic activities [42-45]. 


\subsection{Antimicrobial Activity}

Five different leaf extracts were investigated at a concentration of $10 \mathrm{mg} /$ disc for their antimicrobial activity against five food poisoning bacteria-namely, L. monocytogenes, B. subtilis, S. aureus, E. coli, S. enteritidis-and the fungus C. albicans as well, using the disc diffusion technique. The antimicrobial activity of these leaf extracts was assessed by evaluating the diameter of the inhibition zone (DIZ, mm), as recorded in Table 4. All solvents, as negative controls, had no inhibitory effect against any of the tested microorganisms. The results in Table 4 show that the $\mathrm{MeOH} / \mathrm{H}_{2} \mathrm{O} 80 \%$ and $\mathrm{MeOH}$ extracts exhibited inhibitory effects against all tested bacteria as well as the fungus, while the $\mathrm{H}_{2} \mathrm{O}$ extract was only capable of inhibiting the growth of all tested bacteria. These results are in agreement with the findings of Tatke et al. [37], who found that Rosa damascena methanol extract exerted antimicrobial activity against all tested microorganisms, while water extract did not show any ability as an antifungal (i.e., C. albicans). However, the $\mathrm{C}_{6} \mathrm{H}_{14}$ and $\mathrm{CHCl}_{3}$ extracts were active only against $E$. coli, and these results are consistent with the findings of Halawani [46].

Table 4. Evaluation of in vitro antimicrobial activity of R. gallica var. aegyptiaca leaf extracts.

\begin{tabular}{|c|c|c|c|c|c|c|}
\hline \multirow{4}{*}{ Extract } & \multicolumn{6}{|c|}{ Antimicrobial Activity } \\
\hline & \multicolumn{6}{|c|}{ Diameter of Inhibition Zones (mm) } \\
\hline & \multicolumn{3}{|c|}{ Gram (+) Pathogenic Bacteria } & \multicolumn{2}{|c|}{ Gram (-) Pathogenic Bacteria } & \multirow{2}{*}{$\frac{\text { Fungi }}{\text { C. albicans }}$} \\
\hline & L. monocytogenes & B. subtilis & S. aureus & E. coli & S. enteritidis & \\
\hline $\mathrm{C}_{6} \mathrm{H}_{14}$ & - & - & - & $13 \pm 1.53^{f}$ & - & - \\
\hline $\mathrm{CHCl}_{3}$ & - & - & - & $16 \pm 1.00^{\mathrm{d}}$ & - & - \\
\hline $\mathrm{MeOH}$ & $16 \pm 2.00^{\mathrm{ab}}$ & $19 \pm 1.00^{b}$ & $17 \pm 1.15^{b}$ & $24 \pm 1.15^{\mathrm{ab}}$ & $19 \pm 1.00^{\mathrm{a}}$ & $10 \pm 1.10^{\mathrm{c}}$ \\
\hline $\mathrm{MeOH} / \mathrm{H}_{2} \mathrm{O} 80 \%$ & $17 \pm 0.58^{\mathrm{a}}$ & $20 \pm 0.58^{\mathrm{a}}$ & $17 \pm 1.53^{b}$ & $25 \pm 2.52^{\mathrm{a}}$ & $19 \pm 1.00^{\mathrm{a}}$ & $11 \pm 1.50^{b}$ \\
\hline $\mathrm{H}_{2} \mathrm{O}$ & $12 \pm 0.76^{\mathrm{c}}$ & $12 \pm 1.73^{c}$ & $19 \pm 0.58^{a}$ & $20 \pm 2.00^{c}$ & $18 \pm 1.15^{b}$ & - \\
\hline Gentamycin (10 mg) & $15 \pm 1.00^{b}$ & $12 \pm 1.15^{\mathrm{c}}$ & $16 \pm 0.58^{c}$ & $15 \pm 2.08^{\mathrm{e}}$ & $13 \pm 1.00^{\mathrm{c}}$ & n.d. \\
\hline Fluconazole (10 mg) & n.d. & n.d. & n.d. & n.d. & n.d. & $14 \pm 1.05^{\mathrm{a}}$ \\
\hline
\end{tabular}

$(-)$ No inhibition; values are means $(n=3)$. The concentration of each leaf extract was $10 \mathrm{mg} /$ disc. n.d.: not determined. Means sharing the same letters $\left({ }^{\mathrm{a}-\mathrm{f}}\right)$ for each column are not significantly different according to LSD as a post hoc test at $p \leq 0.05$.

The active extracts had varying degrees of antimicrobial potential against the tested microbial strains. The $\mathrm{MeOH} / \mathrm{H}_{2} \mathrm{O} 80 \%$ extract also showed a superior-excellent antibacterial potency compared with the antibiotic gentamycin. The $\mathrm{MeOH} / \mathrm{H}_{2} \mathrm{O} 80 \%$ extract was found to be the most efficient, and has a broad antibacterial spectrum when tested against both Gram (+) and Gram (-) bacteria, as well as fungi. The susceptible bacteria for the $\mathrm{MeOH} / \mathrm{H}_{2} \mathrm{O} 80 \%$ followed the sequence $E$. coli $>$ B. subtilis $>$ S. enteritidis $>S$. aureus $>$ L. monocytogenes, with the zone of inhibition ranging from $17 \mathrm{~mm}$ to $25 \mathrm{~mm}$. These results are of great importance, especially with respect to $S$. aureus and S. enteritidis, as they are well known for their antibiotic resistance and for producing a variety of enterotoxins that induce various forms of enteritis and septicemia. The antimicrobial activity of the $\mathrm{MeOH} / \mathrm{H}_{2} \mathrm{O} 80 \%$ of $R$. gallica var. aegyptiaca was obviously related to its phenolic and flavonoids components, since HPLC-DAD analysis proved that this extract possesses an appropriate amount of phenolic acids, flavonol, and flavan-3-ol, which are responsible for the activities shown. From these results, $R$. gallica var. aegyptiaca leaf extracts-particularly the $\mathrm{MeOH} / \mathrm{H}_{2} \mathrm{O} 80 \%$ - could be a promising natural preservative against foodborne pathogens for the industry of food production.

2.7. Antimicrobial Activity of the Identified Phenolic Compounds from $\mathrm{MeOH} / \mathrm{H}_{2} \mathrm{O} 80 \%$ Extract of R. gallica var. aegyptiaca Leaves

The antimicrobial activity of the identified phenolic compounds was investigated against the tested microbial strains. The results in Table 5 show that all identified phenolics had antimicrobial effects against all tested microorganisms to varying degrees. Table 5 also shows that the major phenolic component, quercetin, exhibited the highest lethal effect 
against all examined microbial strains. In addition, it possessed strong antibacterial and antifungal activities against tested bacterial and fungal strains, with a zone of inhibition (ZI) ranging from 24 to $30 \mathrm{~mm}$ and $17 \mathrm{~mm}$, respectively-more potent than those of the standard antibacterial and antifungal agents, i.e., gentamycin and fluconazole.

Table 5. Antimicrobial activity of the identified phenolic compounds, represented by diameter of inhibition zone (DIZ, mm).

\begin{tabular}{|c|c|c|c|c|c|c|}
\hline \multirow{4}{*}{ Compounds } & \multicolumn{6}{|c|}{ Antimicrobial Activity } \\
\hline & \multicolumn{6}{|c|}{ Diameter of Inhibition Zones (mm) } \\
\hline & \multicolumn{3}{|c|}{ Gram (+) Pathogenic Bacteria } & \multicolumn{2}{|c|}{ Gram (-) Pathogenic Bacteria } & \multirow{2}{*}{$\begin{array}{c}\text { Fungi } \\
\text { C. albicans }\end{array}$} \\
\hline & L. monocytogenes & B. subtilis & S. aureus & E. coli & S. enteritidis & \\
\hline Gallic acid & $17 \pm 1.10^{b}$ & $16 \pm 1.13^{c}$ & $18 \pm 1.57^{c}$ & $20 \pm 0.45^{b}$ & $18 \pm 1.30^{b}$ & $11 \pm 1.10^{\mathrm{e}}$ \\
\hline Catechin & $16 \pm 0.95^{c}$ & $18 \pm 1.50^{\mathrm{b}}$ & $16 \pm 0.20^{\mathrm{e}}$ & $17 \pm 1.16^{\mathrm{c}}$ & $15 \pm 0.56^{c}$ & $10 \pm 1.35$ ef \\
\hline Chlorogenic acid & $15 \pm 0.35^{\mathrm{d}}$ & $15 \pm 0.50^{\mathrm{cd}}$ & $17 \pm 0.13^{\mathrm{d}}$ & $16 \pm 0.95^{\mathrm{d}}$ & $14 \pm 1.65^{\mathrm{d}}$ & $11 \pm 1.00^{\mathrm{e}}$ \\
\hline Epicatechin & $16 \pm 0.55^{c}$ & $14 \pm 1.02^{\mathrm{d}}$ & $17 \pm 0.50^{\mathrm{d}}$ & $15 \pm 1.40^{\mathrm{e}}$ & $14 \pm 0.33^{\mathrm{d}}$ & $12 \pm 0.85^{\mathrm{d}}$ \\
\hline Quercetin-3-glucoside & $17 \pm 1.02^{b}$ & $18 \pm 0.40^{b}$ & $20 \pm 1.16^{b}$ & $19 \pm 1.22 \mathrm{bc}$ & $17 \pm 0.57^{b c}$ & $15 \pm 1.15^{b}$ \\
\hline Quercetin & $28 \pm 0.57^{a}$ & $25 \pm 0.87^{a}$ & $24 \pm 1.12^{a}$ & $30 \pm 1.18^{a}$ & $26 \pm 0.56^{\mathrm{a}}$ & $17 \pm 0.46^{\mathrm{a}}$ \\
\hline Gentamycin $(10 \mu g)$ & $15 \pm 1.00^{\mathrm{d}}$ & $12 \pm 1.15^{\mathrm{e}}$ & $16 \pm 0.58^{e}$ & $15 \pm 2.08^{\mathrm{e}}$ & $13 \pm 1.00^{\mathrm{e}}$ & n.d. \\
\hline Fluconazole $(10 \mu \mathrm{g})$ & n.d. & n.d. & n.d. & n.d. & n.d. & $14 \pm 1.05^{c}$ \\
\hline
\end{tabular}

n.d.: Not determined. Means sharing the same letters $\left({ }^{\mathrm{a}-\mathrm{f}}\right)$ for each column are not significantly different according to LSD as a post hoc test at $p \leq 0.05$.

It should be noted that there have been no previous studies published on the identification of these compounds from the leaves of R. gallica var. aegyptiaca. Thus, this is the first study on the identification of these antimicrobial phenolics from the leaves of this plant. It has been reported that various isolated flavonoid compounds from plant extracts have potent antimicrobial activity [47-49]. The obtained results indicate that these phenolics—especially quercetin - may be used as lead compounds for the development of new natural antimicrobial agents.

\section{Materials and Methods}

\subsection{Chemicals}

The reference compounds and solvents that were used for the analytical procedures and the extractions-i.e., gallic acid, rutin, L-ascorbic acid, n-hexane, chloroform, methanol, Folin-Ciocalteu reagent, and 1,1-diphenyl-2-picrylhydrazyl (DPPH)-were purchased from Sigma-Aldrich (St. Louis, MO, USA); aluminum chloride and sodium carbonate were of analytical grade.

\subsection{Plant Material}

Fresh leaves of Rosa gallica var. aegyptiaca were collected from Orman Botanical Garden, Giza, Egypt, in August 2020. Taxonomic identification of the plant was established by Professor Dr. T. Labeb at the Horticulture Research Institute, Giza, Egypt. A voucher specimen (No. 125) was deposited in the herbarium of the Biochemistry Department, Faculty of Agriculture, Fayoum University, Fayoum, Egypt. The leaves were washed gently with distilled water to eliminate dust and soil, air-dried in the shade, and then crushed to powder using a laboratory mill through a $24-$ mesh sieve. Powdered materials were stored in an airtight bottle at room temperature $\left(28 \pm 2{ }^{\circ} \mathrm{C}\right)$ and protected from light for further use.

\subsection{Extraction and Isolation}

The dried powder $(100 \mathrm{~g} / 500 \mathrm{~mL})$ of $R$. gallica var. aegyptiaca leaves was taken and extracted with n-hexane $\left(\mathrm{C}_{6} \mathrm{H}_{14}\right)$, chloroform $\left(\mathrm{CHCl}_{3}\right)$, methanol $(\mathrm{MeOH})$, hydromethanol $\left(\mathrm{MeOH} / \mathrm{H}_{2} \mathrm{O} 80 \%\right)$, and water $\left(\mathrm{H}_{2} \mathrm{O}\right)$ individually for three successive days, at room temperature $\left(28 \pm 2{ }^{\circ} \mathrm{C}\right)$, with persistent shaking. The resulting extracts were filtered over a Whatman filter paper No. 1 , and then the combined extract was evaporated at $45^{\circ} \mathrm{C}$ to dryness using a rotary evaporator (R300, BUCHI Labortechnik AG, Flawil, Switzerland). 
All leaf extracts were used separately for screening the antioxidant and antimicrobial activities. The percentage yield was calculated using the following equation:

$$
\text { Extract yield }(\%)=\left(\mathrm{W}_{1} / \mathrm{W}_{2}\right) \times 100
$$

where $W_{1}$ is the weight of extracted plant residues in grams, and $W_{2}$ is the weight of air-dried powdered leaves in grams.

For the isolation of phenolics and flavonoids from the $\mathrm{MeOH} / \mathrm{H}_{2} \mathrm{O} 80 \%$ extract, a known weight of the hydromethanolic extract $(3.5 \mathrm{~g})$ was chromatographed through a silica gel column $(2.7 \mathrm{~cm} \times 60 \mathrm{~cm}, 100 \mathrm{~g})$ using $\mathrm{CHCl}_{3}: \mathrm{MeOH}(100: 0 \rightarrow 0: 100, v / v)$ and monitored via TLC with a suitable system $\left(\mathrm{CHCl}_{3}: \mathrm{MeOH}, 70: 30, v / v\right)$. The eluates were combined on the basis of similarity of TLC profiles to afford 5 fractions (A-E), and were then tested for antioxidant and antimicrobial activity. The active fraction $(C, 1.15 \mathrm{~g})$ was then chromatographed via HPLC-DAD on an RP-18 $(4.6 \times 280 \mathrm{~mm}, 5 \mu \mathrm{m})$, using methanol and water/formic acid $(90: 10, v / v)$ as a mobile phase (flow rate $0.5 \mathrm{~mL} / \mathrm{min}$.), to yield compounds 1 (1.7 mg), 2 (2.9 mg), 3 (1.8 mg), 4 (2.6 mg), 5 (0.5 mg), and 6 (19.8 mg).

\subsection{Qualitative Phytochemical Screening}

Phytochemical detection was carried out to identify the various phytoconstituents present in the leaves of $R$. gallica var. aegyptiaca, using standard phytochemical methods [50-52].

\subsection{DPPH Radical Scavenging Activity}

The ability to scavenge free radicals of all leaf extracts from R. gallica var. aegyptiaca was measured via 1,1-diphenyl-2-picrylhydrazyl (DPPH) free radical assay based on the method described by Brand-Williams et al. [53].

\subsection{Total Phenolic Content Determination (TPC)}

The TPs in the leaf extracts of R. gallica var. aegyptiaca were determined using the Folin-Ciocalteu reagent [54].

\subsection{Total Flavonoid Content Determination (TFC)}

The aluminum chloride method described by Lamaison and Carnet [55] was used to determine TFC in the leaf extracts of R. gallica var. aegyptiaca.

\subsection{HPLC-DAD Analysis}

Isolation and identification of main phenolics were carried out using an HPLC 1100 coupled with a diode array detector (DAD) (model G1315B DAD system; Agilent Technologies, Santa Clara, CA, USA.). The reversed stationary phase employed was a Zorbax $\mathrm{C}_{18}$ column $(280 \times 4.6 \mathrm{~mm}$, internal diameter (i.d.), particle size $5 \mu \mathrm{m}$; Agilent Technologies) with a pre-column $\mathrm{C}_{18}, 5 \mu \mathrm{m}(4 \times 2 \mathrm{~mm}$ i.d., Phenomena, Castel Maggiore, Bologna, Italy). The following gradient system was used with methanol (eluent $\mathrm{A}$ ) and water/formic acid (90:10, $v / v$ ) (eluent B): the flow rate was $0.5 \mathrm{~mL} / \mathrm{min}$, the sample injection was $10 \mu \mathrm{L}$, and the gradient program was initiated from $5 \% \mathrm{~A}, 95 \% \mathrm{~B}(10 \mathrm{~min}) ; 40 \% \mathrm{~A}, 60 \% \mathrm{~B}(20 \mathrm{~min})$; $80 \% \mathrm{~A}, 20 \% \mathrm{~B}$ (50 $\mathrm{min}$ ); 5\% A, 95\%B (55 min); analyses were stopped after $70 \mathrm{~min}$, followed by washing and then re-equilibration of the column. The elution protocol and flow rate were both monitored using an LC-Chem-Station 3D software program (Hewlett-Packard, Palo Alto, CA, USA). DAD was between 250 and $650 \mathrm{~nm}$, and absorbance was recorded at 350,325 , and $280 \mathrm{~nm}$. Identification of phenolic compounds was achieved by comparing the retention times and diode array UV spectra with those of pure standards. The external standard technique was used to quantify phenolics via the integration of the individual peaks. 


\subsection{Antimicrobial Activity}

\subsubsection{Microbial Strains}

The antimicrobial activity of $R$. gallica var. aegyptiaca leaf extracts was tested against five strains of human pathogenic bacteria (i.e., foodborne diseases), including three Gram (+) bacteria (Listeria monocytogenes ATCC 15313, Bacillus subtilis ATCC 7030, and Staphylococcus aureus ATCC 8095) and two Gram (-) bacteria (Escherichia coli ATCC 25922 and Salmonella enteritidis ATCC 13076). Antifungal activity was tested using Candida albicans. These strains were obtained from the Agricultural Microbiology Department, Faculty of Agriculture, Fayoum University (Fayoum, Egypt). The stock cultures of bacteria were maintained on Luria broth (LB) slants, and Candida yeast on potato dextrose agar (PDA) slants, at $4{ }^{\circ} \mathrm{C}$.

\subsubsection{Inoculums Preparation}

Prior to assay, colonies of the tested bacteria and yeast strain were picked from subcultured overnight slants freshly prepared and transferred to $5 \mathrm{~mL}$ LB broth medium for bacteria—or PDA for yeast-and incubated at $37^{\circ} \mathrm{C}$ for $24-48 \mathrm{~h}$ in the case of pathogenic bacteria, and at $30^{\circ} \mathrm{C}$ for $48-72 \mathrm{~h}$ in the case of Candida strain. The density of all culture suspensions was adjusted to the value of the standard equivalent $0.5 \mathrm{McFarland}$ by measurement with the spectrophotometer. The different broth cultures were used to inoculate Petri dishes prior to the antimicrobial assay of plant extracts.

\subsubsection{Antimicrobial Assay}

Antimicrobial assay of each leaf extract against the tested microbial strains was performed using agar disc diffusion assay according to the method described by Bauer et al. [56]. The sterile filter paper discs ( $8 \mathrm{~mm}$ in diameter) were impregnated with $40 \mu \mathrm{L}$ of each plant extract $(10 \mathrm{mg} / 40 \mu \mathrm{L})$ after sterilization by filtration through a $0.22 \mu \mathrm{m}$ membrane filter. The dried sterile filter paper discs loaded with leaf extract of $R$. gallica var. aegyptiaca were placed on the surface of the inoculated plates in triplicate. The inoculated plates were stored in the fridge at $4{ }^{\circ} \mathrm{C}$ for two hours to allow diffusion of leaf extracts, and then incubated as previously described. After this time, the bioactivity was assessed by measuring the diameter of the inhibition zone (DIZ) formed around each disc in $\mathrm{mm}$. As a negative control, a disc containing only $40 \mu \mathrm{L}$ of solvent (without test extract) was employed. For bacteria and fungi, positive controls were gentamycin and fluconazole, respectively. All assays were performed in triplicate, and means ( \pm S.D.) were calculated using the Microsoft Excel program.

\subsection{Statistical Analysis}

All experiments were expressed as mean \pm SD in triplicate. General linear model (GLM) procedures were used to analyze the data. Differences at $p \leq 0.05$ were considered significant using Statistical Package for the Social Sciences (SPSS) software (SPSS, 2019).

\section{Conclusions}

In the current study, the antioxidant and antimicrobial potential of five extractsincluding n-hexane, chloroform, methanol, methanol/water $80 \%$, and water-from the leaves of R. gallica var. aegyptiaca was evaluated, alongside phytochemical analysis. Among the five leaf extracts, hydromethanol $80 \%$ extract possessed the highest extraction yield and total phenolic content, and also exhibited very high antioxidant and antimicrobial activities against all tested microbial strains. Furthermore, six active phenolic compoundsgallic acid (1), (+) catechin (2), chlorogenic acid (3), (-) epicatechin (4), quercetin-3-O- $\alpha-$ D-(glucopyranoside) (5), and quercetin (6) - were identified and quantified from this leaf extract via HPLC-DAD analysis for the first time. Thus, the use of the leaves of this plant as natural antioxidants and antimicrobial sources appears to be a viable alternative to synthetic antioxidants and antimicrobials to alleviate human health hazards associated with the use of these synthetic compounds. 
Supplementary Materials: The following is available online, Figure S1: HPLC-ESI-MS spectra.

Author Contributions: Conceptualization, A.S.A. and A.M.H.A.M.; methodology, A.S.A. and A.M.H.A.M.; software, A.S.A.; validation, A.S.A., A.M.H.A.M. and S.S.A.; formal analysis, A.S.A. and A.M.H.A.M.; investigation, A.S.A. and A.M.H.A.M.; resources, A.S.A. and A.M.H.A.M.; data curation, A.S.A., A.M.H.A.M. and S.S.A.; writing-original draft preparation, A.S.A. and A.M.H.A.M.; writing-review and editing, A.S.A. and A.M.H.A.M.; visualization, A.S.A. and A.M.H.A.M.; supervision, A.S.A.; funding acquisition, A.S.A. and S.S.A. All authors have read and agreed to the published version of the manuscript.

Funding: This research was supported by Fayoum University, Egypt; and by Taif University (TURSP2020/90), Taif, Saudi Arabia.

Institutional Review Board Statement: Not applicable.

Informed Consent Statement: Not applicable.

Data Availability Statement: The data presented in this study are available in this article.

Acknowledgments: The authors are thankful to Marco Negri, Università Degli Studi di Milano for HPLC-DAD analysis, and also to the Taif University Researchers Supporting Project number (TURSP-2020/90), Taif University, Taif, Saudi Arabia.

Conflicts of Interest: The authors declare no conflict of interest.

Sample Availability: Samples of the compounds are not available from the authors.

\section{References}

1. Stanković, N.; Mihajilov-Krstev, T.; Zlatković, B.; Stankov-Jovanović, V.; Mitić, V.; Jović, J.; Bernstein, N. Antibacterial and antioxidant activity of traditional medicinal plants from the Balkan Peninsula. NJAS-Wagening J. Life Sci. 2016, 78, 21-28. [CrossRef]

2. Tortosa, V.; Pietropaolo, V.; Brandi, V.; Macari, G.; Pasquadibisceglie, A.; Polticelli, F. Computational Methods for the Identification of Molecular Targets of Toxic Food Additives. Butylated Hydroxytoluene as a Case Study. Molecules 2020, 25, 2229. [CrossRef] [PubMed]

3. Ham, J.; Lim, W.; You, S.; Song, G. Butylated hydroxyanisole induces testicular dysfunction in mouse testis cells by dysregulating calcium homeostasis and stimulating endoplasmic reticulum stress. Sci. Total Environ. 2020, 702, 134775. [CrossRef]

4. Ham, J.; Lim, W.; Whang, K.Y.; Song, G. Butylated hydroxytoluene induces dysregulation of calcium homeostasis and endoplasmic reticulum stress resulting in mouse Leydig cell death. Environ. Pollut. 2020, 256, 113421. [CrossRef] [PubMed]

5. Eskandani, M.; Hamishehkar, H.; Ezzati Nazhad Dolatabadi, J. Cytotoxicity and DNA damage properties of tertbutylhydroquinone (TBHQ) food additive. Food Chem. 2014, 153, 315-320. [CrossRef]

6. Sapkota, R.; Dasgupta, R.; Nancy, D.S. Antibacterial effects of plants extracts on human microbial pathogens \& microbial limit tests. Int. J. Res. Pharm. Chem. 2012, 2, 926-936.

7. Silva, M.M.; Lidon, F. Food preservatives. An overview on applications and side effects. Emirates J. Food Agric. 2016, 26, 366-373. [CrossRef]

8. Mostafa, A.A.; Al-Askar, A.A.; Almaary, K.S.; Dawoud, T.M.; Sholkamy, E.N.; Bakri, M.M. Antimicrobial activity of some plant extracts against bacterial strains causing food poisoning diseases. Saudi J. Biol. Sci. 2018, 25, 361-366. [CrossRef]

9. Solomakos, N.; Govaris, A.; Koidis, P.; Botsoglou, N. The antimicrobial effect of thyme essential oil, nisin and their combination against Escherichia coli O157:H7 in minced beef during refrigerated storage. Meat Sci. 2008, 80, 159-166. [CrossRef]

10. Pandey, A.; Singh, P. Antibacterial activity of Syzygium aromaticum (Clove) with metal ion effect against food borne pathogens. Asian J. Plant Sci. Res. 2011, 1, 69-80.

11. Braga, L.C.; Shupp, J.W.; Cummings, C.; Jett, M.; Takahashi, J.A.; Carmo, L.S. Pomegranate extract inhibits Staphylococcus aureus growth and subsequent enterotoxin production. J. Ethnopharmacol. 2005, 96, 335-339. [CrossRef] [PubMed]

12. Celiktas, O.Y.; Kocabas, E.E.H.; Bedir, E.; Sukan, F.V.; Ozek, T.; Baser, K.H.C. Antimicrobial activities of methanol extracts and essential oils of Rosmarinus oficinalis, depending on location and seasonal variations. Food Chem. 2007, 100, 553-559. [CrossRef]

13. Atef, N.M.; Shanab, S.M.; Negm, S.I.; Abbas, Y.A. Evaluation of antimicrobial activity of some plant extracts against antibiotic susceptible and resistant bacterial strains causing wound infection. Bull. Natl. Res. Cent. 2019, 43, 1-11. [CrossRef]

14. Manandhar, S.; Luitel, S.; Dahal, R.K. In vitro antimicrobial activity of some medicinal plants against human pathogenic bacteria. J. Trop. Med. 2019, 2019, 1895340. [CrossRef]

15. Brown, D. New Encyclopedia of Herbs \& Their Uses, 1st ed.; Dorling Kindersley: London, UK, 2002; pp. $346-347$.

16. Bitis, L.; Sen, A.; Ozsoy, N.; Birteksoz-Tan, S.; Kultur, S.; Melikoglu, G. Flavonoids and biological activities of various extracts from Rosa sempervirens leaves. Biotechnol. Biotechnol. Equip. 2017, 31, 299-303. [CrossRef]

17. Caliskan, U.K.; Aka, C.; Oz, M.G. Plants used in anatolian traditional medicine for the treatment of hemorrhoid. Rec. Nat. Prod. 2017, 11, 235-250. 
18. Lattanzio, F.; Greco, E.; Carretta, D.; Cervellati, R.; Govoni, P.; Speroni, E. In vivo anti-inflammatory effect of Rosa canina L. extract. J. Ethnopharmacol. 2011, 137, 880-885. [CrossRef]

19. Barros, L.; Carvalho, A.M.; Morais, J.S.; Ferreira, I.C.F.R. Strawberry-tree, blackthorn and rose fruits: Detailed characterization in nutrients and phytochemicals with antioxidant properties. Food Chem. 2010, 120, 247-254. [CrossRef]

20. Willich, S.N.; Rossnagel, K.; Roll, S.; Wagner, A.; Mune, O.; Erlendson, J.; Kharazmi, A.; Sörensen, H.; Winther, K. Rose hip herbal remedy in patients with rheumatoid arthritis-A randomized controlled trial. Phytomedicine 2010, 17, 87-93. [CrossRef]

21. Mármol, I.; Sánchez-de-Diego, C.; Jiménez-Moreno, N.; Ancín-Azpilicueta, C.; Rodríguez-Yold, M.J. Therapeutic Applications of Rose Hips from Different Rosa Species. Int. J. Mol. Sci. 2017, 18, 1137. [CrossRef] [PubMed]

22. Knapp, H.; Straubinger, M.; Fornari, S.; Oka, N.; Watanabe, N.; Winterhalter, P. (S)-3,7-dimethyl-5-octene-1,7-diol and related oxygenated monoterpenoids from petals of Rosa damascena Mill. J. Agric. Food Chem. 1998, 46, 1966-1970. [CrossRef]

23. Kumar, N.; Bhandari, P.; Singh, B.; Gupta, A.P.; Kaul, V.K. Reversed phase-HPLC for rapid determination of polyphenols in flowers of rose species. J. Sep. Sci. 2008, 31, 262-267. [CrossRef]

24. Oka, N.; Ikegami, A.; Ohki, M.; Sakata, K.; Yagi, A.; Watanabe, N. Citronellyl disaccharide glycoside as an aroma precursor from rose flowers. Phytochemistry 1998, 47, 1527-1529. [CrossRef]

25. Bitis, L.; Kultur, S.; Melikoglu, G. Flavonoids and antioxidant activity of Rosa agrestis leaves. Nat. Prod. Res. 2010, 24, 580-589. [CrossRef]

26. Mileva, M.M.; Kusovski, V.K.; Krastev, D.S. Chemical composition, in vitro antiradical and antimicrobial activities of Bulgarian Rosa alba L. essential oil against some oral pathogens. Int. J. Curr. Microbiol. App. Sci. 2014, 3, 11-20.

27. Mileva, M.; Krumova, E.; Miteva-Staleva, J. Chemical compounds, in vitro antioxidant and antifungal activities of some plant essential oils belonging to Rosaceae family. C. R. Acad. Bulg. Sci. 2014, 67, 1363-1368.

28. Nowak, R.; Gawlik-Dziki, U. Polyphenols of Rosa, L. leaves extracts and their radical scavenging activity. Z. Nat. 2007, 62c, 32-38. [CrossRef] [PubMed]

29. Cendrowski, A.; Kraśniewska, K.; Przybył, J.L.; Zielińska, A.; Kalisz, S. Antibacterial and antioxidant activity of extracts from rose fruits (Rosa rugosa). Molecules 2020, 25, 1365. [CrossRef]

30. Ercisli, S. Chemical composition of fruits in some rose (Rosa spp.) species. Food Chem. 2007, 104, 1379-1384. [CrossRef]

31. Sudjaroen, Y.; Haubner, R.; Würtele, G.; Hull, W.E.; Erben, G.; Spiegelhalder, B.; Changbumrunga, S.; Bartschb, H.; Owen, R.W. Isolation and structure elucidation of phenolic antioxidants from Tamarind (Tamarindus indica L.) seeds and pericarp. Food Chem. Toxicol. 2005, 43, 1673-1682. [CrossRef] [PubMed]

32. Moussa, A.M.; Emam, A.M.; Diab, Y.M.; Mahmoud, M.E.; Mahmoud, A.S. Evaluation of antioxidant potential of 124 Egyptian plants with emphasis on the action of Punica granatum leaf extract on rats. Int. Food Res. J. 2011, 18, 532-539.

33. Dehghan, K.A.; Rasooli, I.; Rezaee, M.B.; Owlia, P. Antioxidative properties and toxicity of white rose extract. Iranian J. Toxicol. 2011, 5, 415-425.

34. Chen, J.; Yang, J.; Ma, L.; Li, J.; Shahzad, N.; Kim, C.K. Structure-antioxidant activity relationship of methoxy, phenolic hydroxyl, and carboxylic acid groups of phenolic acids. Sci. Rep. 2020, 10, 1-9.

35. Ozkan, G.; Sagdic, O.; Baydar, N.G.; Baydar, H.A.S.A.N. Antioxidant and antibacterial activities of Rosa damascena flower extracts. Food Sci. Technol. Int. 2004, 10, 277-281. [CrossRef]

36. Peschel, W.; Sanchez-Rabaneda, F.; Dn, W.P.A.; Gartzia, I.; Jimenez, D.; Lamuela-Raventos, R.M.; Buxaderas, S.; Condina, C. An industrial approach in the search of natural antioxidants from vegetable and fruit wastes. Food Chem. 2006, 97, 137-150. [CrossRef]

37. Tatke, P.; Satyapal, U.S.; Mahajan, D.C.; Naharwar, V. Phytochemical Analysis, In-Vitro Antioxidant and Antimicrobial Activities of Flower Petals of Rosa damascena. Int. J. Pharmacogn. Phytochem. Res. 2015, 7, 246-250.

38. Zieliński, H.; Achremowicz, B.; Przygodzka, M. Antioxidants of cereal grains. Żywność. Nauka Technol. Jakość. $2012,1,5-26$.

39. Giada, M.D.L.R. Food phenolic compounds: Main classes, sources and their antioxidant power. Oxid. Stress Chronic Degener. Dis. 2013, 2013, 87-112.

40. Sang, S.; Lapsley, K.; Jeong, W.S.; Lachance, P.A.; Ho, C.T.; Rosen, R.T.J. Antioxidative phenolic compounds isolated from almond skins (Prunus amygdalus Batsch). J. Agric. Food Chem. 2002, 50, 2459-2463. [CrossRef]

41. Palafox-Carlos, H.; Yahia, E.M.; Gonzáles-Aguilar, G.A. Identification and quantification of major phenolic compounds (Mangifera indica, cv. Ataulfo) fruit by HPLC-DAD-MS/MS-ESI and their individual contribution to the antioxidant activity during ripening. Food Chem. 2012, 135, 105-111. [CrossRef]

42. David, A.V.A.; Arulmoli, R.; Parasuraman, S. Overviews of biological importance of quercetin: A bioactive flavonoid. Pharm. Rev. 2016, 10, 84.

43. Hashemzaei, M.; Delarami Far, A.; Yari, A.; Heravi, R.E.; Tabrizian, K.; Taghdisi, S.M.; Rezaee, R. Anticancer and apoptosisinducing effects of quercetin in vitro and in vivo. Oncol. Rep. 2017, 38, 819-828. [CrossRef]

44. Salehi, B.; Machin, L.; Monzote, L.; Sharifi-Rad, J.; Ezzat, S.M.; Salem, M.A.; Cho, W.C. Therapeutic potential of quercetin: New insights and perspectives for human health. ACS Omega 2020, 5, 11849-11872. [CrossRef]

45. Yang, D.; Wang, T.; Long, M.; Li, P. Quercetin: Its main pharmacological activity and potential application in clinical medicine. Oxid. Med. Cell. Longev. 2020, 2020, 8825387. [CrossRef]

46. Halawani, E.M. Antimicrobial activity of Rosa damascena petals extracts and chemical composition by gas chromatography-mass spectrometry (GC/MS) analysis. Afr. J. Microbiol. Res. 2014, 8, 2359-2367. 
47. Górniak, I.; Bartoszewski, R.; Króliczewski, J. Comprehensive review of antimicrobial activities of plant flavonoids. Phytochem. Rev. 2019, 18, 241-272. [CrossRef]

48. Kebede, T.; Gadisa, E.; Tufa, A. Antimicrobial activities evaluation and phytochemical screening of some selected medicinal plants: A possible alternative in the treatment of multidrug-resistant microbes. PLOS ONE 2021, 16, e0249253.

49. Biharee, A.; Sharma, A.; Kumar, A.; Jaitak, V. Antimicrobial flavonoids as a potential substitute for overcoming antimicrobial resistance. Fitoterapia 2020, 146, 104720. [CrossRef] [PubMed]

50. Harbone, J.B. Phytochemical Methods; Chapman and Hall: London, UK, 1998; pp. 117-119.

51. Farnsworth, N.R. Biological and phytochemical screening of plants. J. Pharm. Sci. 1966, 55, 225-276. [CrossRef] [PubMed]

52. Rangari, V.D. Pharmacognosy and Phytochemistry; Carrier Publication: Nashik, Indian, 2002; p. 132.

53. Brand-Williams, W.; Cuvelier, M.E.; Berset, C. Use of a free radical method to evaluate antioxidant activity. Lebensm. Wissenchaft und Technol. 1995, 28, 25-30. [CrossRef]

54. Yu, L.; Haley, S.; Perret, J.; Harris, M.; Wilson, J.; Qian, M. Free radical scavenging properties of wheat extracts. J. Agric. Food Chem. 2002, 50, 1619-1624. [CrossRef] [PubMed]

55. Lamaison, J.L.C.; Carnet, A. Teneurs en principaux flavonoides des fleurs de Crataegus monogyna Jacq et de Crataegus Laevigata (Poiret, D.C) en fonction de la vegetation pharmaceut. Acta Helve. 1990, 65, 315-320.

56. Bauer, A.W.; Kirby, M.M.; Sherris, J.C.; Turck, M. Antibiotic susceptibility testing by a standardized single disk method. Amr. J. Clin. Pathol. 1966, 45, 493-496. [CrossRef] 